Jurnal Litbang Provinsi Jawa Tengah

Vol. 19, No. 2, Desember 2021, hal. 123 - 136

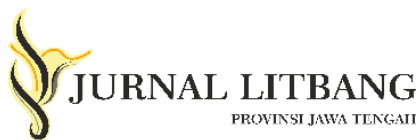

\title{
Stakeholders Mapping Dalam Pelaksanaan Community Tourism Collabortaive Governance (CTCG) Di Desa Maron Wonosobo
}

\author{
Stakeholderss Mapping in The Implementation of \\ Community Tourism Collaborative Governance \\ (CTCG) in Maron Village Wonosobo
}

Ika Nur Afni

Ilmu Administrasi Negara, Fisip, Universitas Slamet Riyadi

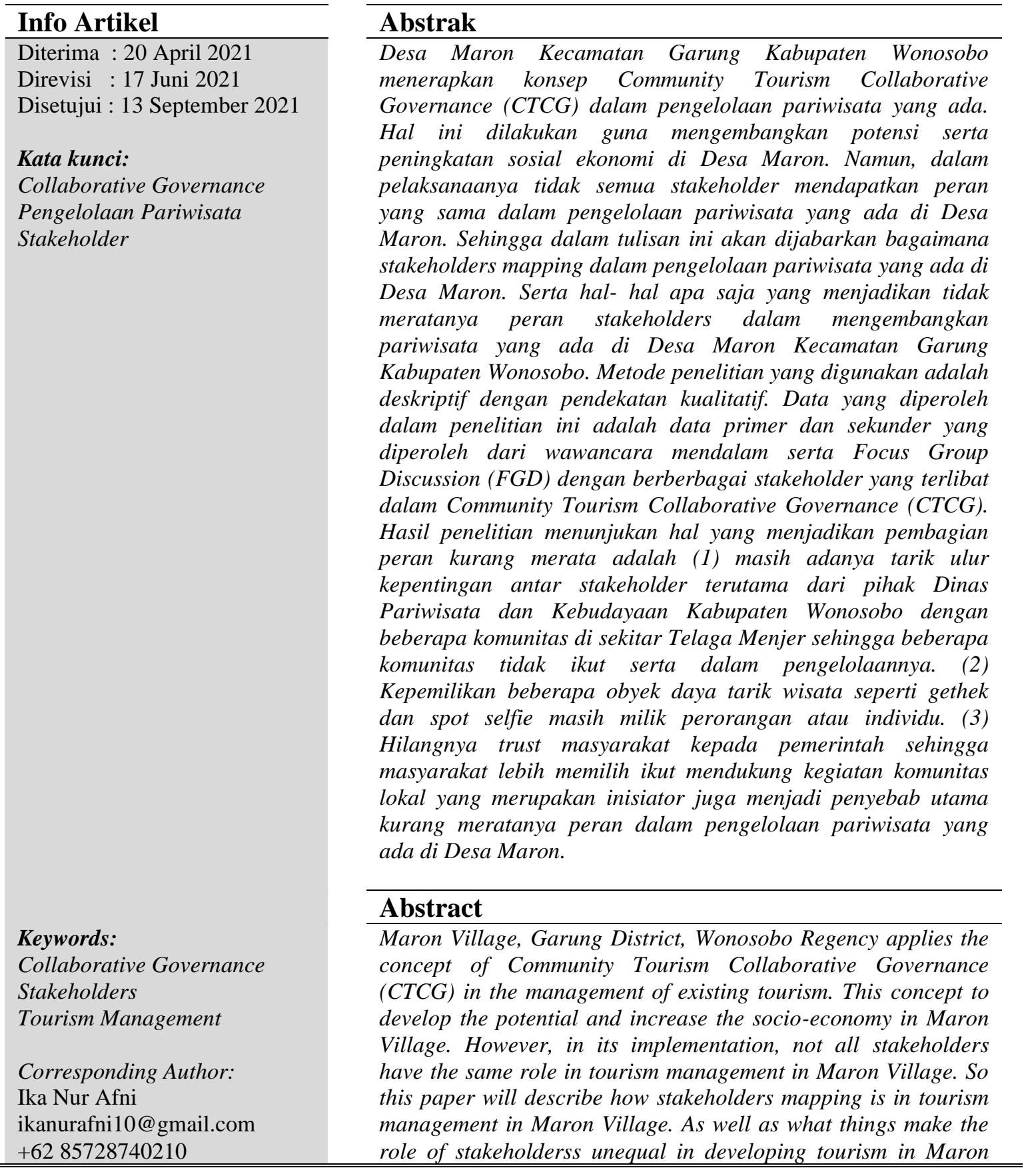

http://ejournal.bappeda.jatengprov.go.id/index.php/jurnaljateng 
Village, Garung District, Wonosobo Regency. The research is descriptive with a qualitative approach. The data obtained in this study are primary and secondary data obtained from in-depth interviews and Focus Group Discussions (FGD) with various stakeholderss involved in Community Tourism Collaborative Governance (CTCG). The results show that the things that divide roles uneven are (1) there is still a tug of war between stakeholderss, especially from the Tourism and Culture Office of Wonosobo Regency with several communities around Menjer Lake so that some communities do not participate in its management. (2) Ownership of several tourist attraction objects such as gethek and selfie spots still belongs to individuals. (3) The loss of public trust in the government so that the community prefers to support local community activities which are the initiators of tourism management in Maron Village.

\section{PENDAHULUAN}

Pariwisata dapat menumbuhkan dan meningkatkan pengenalan budaya dan rasa cinta tanah air. Sektor pariwisata juga memberikan sumbangan terhadap Pendapatan Asli Daerah bersumber dari pajak dan karcis atau mendapatkan devisa dari dari para wisatawan yang berkunjung. Adanya kegiatan pariwisata juga menumbuhkan usaha-usaha ekonomi di sekitar area wisata dan menunjang kegiatannya sehingga dapat meningkatkan pendapatan masyarakat (Al Fajri, 2019; Alamsyah et al., 2019).

Pariwisata berbasis komunitas dapat menjadi solusi untuk mengatasi permasalahan yang ada di daerah. Hal- hal yang dimaksud adalah; (1) Pertumbuhan ekonomi, diversi dan stabilisasi UKM, menciptakan pasar untuk berbagai produk agricultur serta perluasan basis ekonomi daerah. (2) Pengembangan budaya lokal termasuk pelayanan publik, revitalisasi kerajinan lokal, penguatan identitas daerah, meningkatkan kesempatan untuk melakukan perubahan sosial. (3) perlindungan dan peningkatan pembangunan berkelanjutan yang ramah lingkungan serta mendukung konservasi lokal (Keyim, 2015).

Sifat industri pariwisata yang saat ini memiliki fragmentasi tinggi serta saling ketergantungan lintas ruang geografis menyebabkan situasi dimana tata kelola dan regulasi tidak hanya diserahkan ditangan negara saja tetapi juga ditangan banyak pelaku dan kelompok kepentingan yang berbeda-beda. Keberhasilan pembangunan pariwisata di suatu daerah tidak hanya berhenti pada stakeholders saja, namun stakeholders tersebut harus berkolaborasi (Irene and Sitorus, 2020).

Hal tersebut juga sejalan dengan paradigma Governance dalam ilmu administrasi negara yaitu mendorong peran pemerintah kepada kelompok lain untuk membangun sinergitas dalam tata kelola pemerintah yang baik. Pada perkembangan selanjutnya terjadi penyempurnaan yaitu collaborative governance yang dimaknai bahwa institusi publik atau pihak kepentingan dalam pelaksanaan tujuan suatu kebijakan atau program harus melibatkan secara konsensus dalam perumusan dan partisipatif dalam melaksanakan kebijakan tersebut (Yashinta, 2020).

Tata kelola kolaboratif itu sendiri mengacu pada kerjasama stakeholders negara dan non negara untuk mengatur masyarakat secara efisien dan adil (Keyim, 2016). Pada sektor pariwisata, pendekatan tata kelola kolaboratif yang adil dan efektif dapat diarahkan untuk mempromosikan kewirausahaan yang memberikan kontribusi yang positif bagi pengembangan sosial ekonomi masyarakat yang mempunyai berbagai permasalahan (Keyim, 2016).

Pada pengelolaan pariwisata tidak ada stakeholders tunggal yang memiliki akses ke sumber daya promosi pengembangan pariwisata yang berkelanjutan. Dengan

Stakeholders Mapping dalam Pelaksanaan Community Tourism Collabortaive Governance (CTCG) di Desa 
demikian makna dari kolaborasi yaitu adanya integrasi yang terjadi antara berbagai stakeholders pemerintah maupun non pemerintah dalam memanfaatkan sumber daya yang ada (pengetahuan, keahlian dan modal) dengan tujuan memaksimalkan kontribusi sosial dan ekonomi pariwisata setempat (Keyim, 2018)

Stakeholders yang dapat ikut andil dalam pengembangan pariwisata selain pemerintah adalah masyarakat, komunitas lokal serta pihak swasta yang ada di sekitar obyek wisata (Hidayah et al., 2019). Sehingga dalam pelaksanaanya harus saling berkolaborasi untuk memaksimalkan pengembangan pariwisata yang ada. Kolaborasi yang lebih luas dan merata dalam pengambilan keputusan serta implementasi dapat menjadikan mekanisme yang dinamis untuk menyelesaikan beberapa konflik terkait pengembangan pariwisata lokal, memobilitasi secara efektif sumber daya manusia, alam dan budaya setempat (Keyim, 2018)

Konsep stakeholders merupakan individu atau kelompok yang dapat mempengaruhi atau dipengaruhi oleh suatu organisasi sebagai dampak dari aktivitasnya. Stakeholders dalam kondisi atau waktu tertentu juga dapat dipengaruhi oleh suatu organisasi dalam mencapai tujuan organisasi (Thondhlana, Shackleton dan Blignaut, 2015). Keterlibatan stakeholders menghasilkan perencanaan strategi pariwisata dan koordinasi berbagai peran stakeholders dalam suatu destinasi pariwisata juga membentuk citra destinasi pariwisata yang berkualitas dan mudah dikenali (Destiana et al., 2020).

Desa Maron sebagai salah satu desa yang memiliki potensi pariwisata yang potensial untuk dikembangkan telah melalukan beberapa strategi pengembangan salah satunya dengan menjalin kemiteraan dalam mengembangkan obyek wisatanya. Telaga Menjer sendiri terletak pada Kecamatan Garung Kabupaten Wonosobo, satu arah dengan obyek wisata Dataran Tinggi Dieng. Telaga Menjer merupakan salah satu wisata unggulan di Kabupaten Wonosobo yang terletak di Desa Maron dikelola oleh tiga sektor, yakni Desa Maron, Dinas Pariwisata dan Kebudayaan Kabupaten Wonosobo serta PT. Indonesia Power. Keterlibatan PT. Indonesia Power ini melalui perjanjian kerjasama dengan organisasi masyarakat yang ada di Desa Maron. Kerjasama yang dilakukan dengan PT. Indonesia Power sejak tahun 2017 ini mempunyai tujuan untuk pengembangan pariwisata, meningkatkan kompetensi masyarakat, mendatangkan pendapatan daerah dan mengangkat cerita dan profil daerah ke mancanegara.

Pada pengelolaan pariwisata di Desa Maron masih terdapat berbagai permasalahan yang muncul. Permasalahan adalah belum meratanya peran pengelolaan pariwisata yang ada di Desa Maron. Seperti yang disebutkan diatas bahwa di Desa Maron sudah terdapat berbagai komunitas yang bergerak dalam pengelolaan pariwisata. Namun pada pelaksanaanya tidak semua komunitas mendapatkan peran yang sama dalam pengelolaan pariwistaa yang ada di Desa Maron. Salah satunya Kelompok Sadar Wisata Lembah Seroja tidak ikut andil dalam pengelolaan Obyek Wisata Telaga Menjer. Hal ini disampaikan oleh wakil Kelompok Sadar Wisata Lembah Seroja mengungkapkan bahwa pengelolaan Telaga Menjer didominasi oleh Karang Taruna Karya Persada dan Dinas Pariwisata dan Kebudayaan Kabupaten Wonosobo.

Sehingga dalam tulisan ini akan dijabarkan bagaimana stakeholders mapping dalam pengelolaan pariwisata yang ada di Desa Maron. Tujuan lainnya adalah mengidentifikasi hal-hal apa saja yang menjadikan tidak meratanya peran stakeholders dalam mengembangkan pariwisata yang ada di Desa Maron Kecamatan Garung Kabupaten Wonosobo.

\section{METODE}

Desain penelitian ini menggunakan pendekatan deskriptif kualitiatif, pengumpulan data dilakukan selama kurang 
lebih dua bulan. Data yang diperoleh dari hasil wawancara dan observasi secara langsung dengan pelaku kolaborasi pariwisata di Desa Maron. Wawancara yang dilakukan adalah wawancara semi struktural yang mempunyai tujuan untuk mendapatkan hasil yang lebih mendalam (Cresswell, 2012). Wawancara dilakukan dengan beberapa stakeholder yang terlibat dalam kolaborasi pariwisata meliputi; Dinas Pariwisata dan Kebudayaan Kabupaten Wonosobo, Pemerintah Desa Maron, Karang Taruna Karya Persada, Kelompok Sadar Wisata Lembah Seroja, BUMDes Sumber Lancar Maron, PT. Indonesia Power serta masyarakat yang ada di Desa Maron.

Peneliti tidak membatasi jumlah informan yang ada, namun berpatokan kedalam informasi yang diperoleh. Pada kurun waktu dua bulan penelitian, peneliti hanya dapat mewawancarai sepuluh informan saja. Para informan ini merupakan pelaku wisata dan pengelola yang terlibat dalam tata telola kolaborasi yang ada di Desa Maron. Selain menggunakan metode wawancara, pada penelitian ini juga menggunakan metode Focus Group Discussion (FGD) yang dilakukan bersama dengan peneliti dari Lembaga Ilmu Pengetahuan Indonesia (LIPI), PT. Indonesia Power, beberapa Satuan Kerja Perangkat Daerah Kabupaten Wonosobo, Pemerintah Desa Maron serta Komunitas Lokal yang terlibat dalam Community Tourism Collaborative Governance (CTCG) di Desa Maron.

Informasi yang peneliti adalah informasi yang terkait dengan Community Tourism Collaborative Governance (CTCG). Pertanyaan yang peneliti ajukan adalah berkaitan dengan tugas, fungsi, kemampuan, program, hambatan yang dihadapi dari beberapa organisasi yang terlibat dalam $C T C G$. Pencarian informasi yang peneliti lakukan selama dua bulan lebih banyak dan intens dari pihak pengelola di sekitar Obyek Wisata Desa Maron. Masalah atau kendala yang peneliti alami berkaitan dengan terbatasnya penelitian terdahulu yang belum banyak mengkaji tentang Community Tourism Collaborative Governance (CTCG). Peneliti mengalami kesulitan dalam menentukan indikator untuk menganalisis Community Tourism Collaborative Governance (CTCG) dalam pengembangan pariwisata yang ada di Desa Maron Kecamatan Garung Kabupaten Wonosobo.

Analisis pada penelitian ini menggunakan salah satu indikator pada model Community Tourism Collaborative Governance (CTCG) yang dikemukakan oleh Parhard Keyim di beberapa penelitiannya pada tahun 2015- 2018 (Keyim, 2015, 2016, 2018). Salah satu indikator dalam konsep Community Tourism Collaborative Governance (CTCG) adalah kolaborasi yang luas dan adil, dalam artian pariwisata di masyarakat bisa menjadi industri yang melibatkan banyak stakeholders dari sektor publik, komunitas bisnis/ swasta dan komunitas lokal yang ada di desa itu sendiri.

\section{HASIL DAN PEMBAHASAN}

Konsep Community

Tourism

Collabrative Governance (CTCG) mulai digunakan oleh (Keyim, 2016) melalui penelitiannya berjudul Tourism Collaborative and rural community develompent: case studies from Finland and China. Penelitian ini mempunyai tujuan untuk melihat dampak sosial ekonomi terhadap masyarakat dari pengembangan pariwisata di beberapa negara berkembang khususnya Finlandia dan China dari sudut pandang $C T C G$. Pengembangan komunitas tidak dapat dicapai tanpa keberlanjutan komunitas itu sendiri. Sehingga komunitas lokal perlu untuk diberdayakan dan dikelola. Mereka diberikan kewenangan dan otoritas sendiri supaya kedepannya mampu mandiri dan dapat menyelesaikan permasalahan pada bidang pariwisata di wilayahnya (Kusiawati, 2017; Ahsani et al., 2018).

$$
\text { Konsep Community Tourism }
$$

Collaborative Governance (CTCG) menggunakan beberapa indikator yang 
Jurnal Litbang Provinsi Jawa Tengah, Vol. 19, No. 2, Desember 2021, hal. 123-136

digunakan untuk menganalisis Collaborative Governance dalam pengembangan pariwisata di Desa Maron. Penelitianyang dilakukan oleh Parhard Keyim 2016 dan 2017 masih menggunakan tiga indikator utama yaitu; kolaborasi yang luas dan adil, penyelenggara yang sah dan terampil; sumber daya yang memadahi. Tiga indikator yang digunakan tersebut untuk menjawab pengaruh Community Tourism Collaborative Governance (CTCG) dengan kesejahtetaan komunitas lokal dan masyarakat (Keyim, 2015, 2016, 2018). Tulisan ini akan berfokus pada indikator kolaborasi yang luas dan adil, hal ini dikarenakan masih terdapat beberapa komunitas sosial/stakeholders yang tidak mendapatkan peran terkait pengelolaan dan pengembangan pariwisata yang ada di Desa Maron.
Pada
Community
Tourism

Collaborative Governance (CTCG) di Desa Maron juga melibatkan banyak stakeholders dari pemerintah, bisnis dan juga komunitas dari masyarakat. Stakeholders yang terlibat yaitu; Dinas Pariwisata dan Kebudayaan Kabupaten Wonosobo, Pemerintah Desa Maron, Badan Usaha Milik Desa (BUMDes) Sumber Lancar Maron, Karang Taruna Karya Persada, Kelompok Sadar Wisata Desa Maron dan PT. Indonesia Power. Adapun beberapa profil dari stakeholder yang terlibat dalam pengelolaan pariwisata di Desa Maron sebagai berikut:

\section{Peran Stakeholders dalam CTCG di Desa Maron}

a. Dinas Pariwisata dan Kebudayaan Kabupaten Wonosobo

Dinas Pariwisata dan Kebudayaan

Kabupaten Wonosobo menjalankan

fungsinya sebagai Perumus Kebijakan;

Pelaksana Koordinasi; Pelaksana Kebijakan;

Pelaksana Pengembangan Strategi; Pelaksana

Pembinaan; Pelaksana Pelayanan Umum;

Pelaksana Monitor; Pelaksana

Kesekretariatan Dinas; Pelaksana fungsi

lainnya. Pada pengelolaan dan pengembangan pariwisata yang ada di Desa Maron Dinas Pariwisata dan Kebudayaan
Kabupaten Wonosobo berperan sebagai regulator kebijakan saja sedangkan implementasinya dilakukan oleh Pemerintah Desa serta komunitas masyakat yang ada di Desa Maron. Selain itu di wilayah Telaga Menjer juga banyak sekali tarik ulur kepentingan antar lembaga baik dari pemerintah maupun non pemerintah.

Hal ini yang menyebabkan sebagian wilayah dikelola oleh Dinas Pariwisata dan Kebudayaan Kabupaten Wonosobo, sebagian wilayah oleh Desa Tlogo serta sebagian wilayah oleh Desa Maron dan Karang Taruna Karya Persada. Selain itu, Dinas Pariwisata dan Kebudayaan Kabupaten Wonosobo memiliki peran sebagai pendamping bagi beberapa komunitas penggelola pariwisata seperti Kelompok Sadar Wisata. Di Desa Maron sendiri terdapat Kelompok Sadar Wisata binaan. Sehingga peran Dinas Pariwisata selain sebagai regulator juga sebagai pendamping bagi Kelompok Sadar Wisata yang ada di beberapa wilayah guna mengembangkan potensi pariwisata yang ada. Dinas Pariwisata dan Kebudayaan Kabupaten Wonosobo hadir apabila terdapat beberapa event besar saja. Selain itu adanya konflik dengan beberapa komunitas lokal yang ada di Desa Maron juga menyebabkan Dinas Pariwisata dan Kebudayaan Kabupaten Wonosobo tidak dapat melakukan pengelolaan yang maksimal terhadap obyek wisata yang ada di Desa Maron.

\section{b. Pemerintah Desa Maron}

Pemerintah Desa Maron sebagai salah satu otoritas lokal yang ada di Desa Maron memiliki berbagai upaya untuk mengembangkan dari berbagai sektor yang ada di wilayahnya salah satunya adalah pariwisata Desa Maron yang terletak di Lereng Gunung Seroja memiliki potensi yang dapat dikembangkan seperti kuliner olahan ikan khas Menjer, tempat penginapan, lahan pertanian kopi, selfie dek, bumi perkemahan, kesenian tradisional. Selain itu juga obyek wisata Telaga Menjer yang secara administrasi masuk ke dalam Desa Menjer. 
Pemerintah Desa Maron sadar betul bahwa pariwisata ini mampu meningkatkan pendapatan desa karena lahan pertanian yang ada di Maron sangat terbatas, sehingga salah satu cara meningkatkan ekonomi dan kesejahteraan masyarakatnya melalui pariwisata, sehingga masyarakat tidak hanya bergantung pada sektor pertanian saja

Pariwisata menjadi salah satu senjata bagi Pemerintah Desa Maron untuk mendongkrak ekonomi desa. Namun, Pemerintah Desa Maron juga belum mampu memberikan dukungan anggaran yang optimal untuk pengelolaan pariwisata di Desa Maron. Hal ini dikarenakan terdapat beberapa hal yang harus diprioritaskan

Untuk mencapai keberhasilan pembangunan melalui pariwisata, Pemerintah Desa Maron berupaya membentuk BUMDes Sumber Lancar Maron guna menampung semua komunitas yang ada disana. BUMDes ini diharapkan mampu mengoptimalkan partisipasi masyarakat serta mampu meningkatkan ekonomi masyarakat itu sendiri. Pemerintah Desa juga mendukung semua kegiatan pariwisata di Desa Maron baik yang dilakukan oleh Kelompok Sadar Wisata, Karang Taruna serta komunitas lokal.

\section{c. PT. Indonesia Power}

Kegiatan pembangkit listrik oleh PLTA Garung yang ada di wilayah Telaga Menjer yang berada di wilayah Desa Maron dan Desa Tlogo ini tentu saja membahayakan kawasan tersebut. Bahkan Kecamatan Garung termasuk Desa Maron masuk dalam kawasan Ring 1 yang harus dilindungi karena adanya aktivitas pembangkit listrik tenaga air. PLTA Garung harus menjamin keselamatan serta mengoptimalkan pemberdayaan masyarakat sekitar sebagai jaminan keamanan.

Bentuk kegiatan CSR yang dilakukan oleh PT. Indonesia Power adalah melalui kegiatan kerjasama. Kerjasama yang dilakukan oleh Desa Maron dengan PT Indonesia Power adalah penyewaan lahan.
Sebagian besar lahan di sekitar Telaga Menjer dan Desa Maron merupakan milik Indonesia Power. Lahan itu disewa untuk lahan pertanian serta pengembangan kawasan wisata yang ada di Desa Maron. Pada obyek wisata misalnya, Karang Taruna Karya Persada dan Kelompok Sadar Wisata Desa Maron menyewa lahan untuk kegiatan pariwisata yaitu berupa Camping Ground serta spot swafoto dengan view Telaga Menjer. Selain itu, di sekeliling Telaga Menjer lahan disewa untuk menanam kopi dan pinus yang dikelola oleh warga Desa Maron

Lahan pertanian disekitar Telaga Menjer juga disewakan oleh Indonesia Power untuk dikelola oleh warga. Harga sewa per $\mathrm{m}^{2}$ adalah $\mathrm{Rp} 25,00$. Kerjasama ini dilakukan pada tahun 2009 silam antara Pemerintah Desa Maron dengan PT Indonesia Power. Hal ini dilakukan sebagai upaya memaksimalkan hasil bumi yang ada di Desa Maron. Selain itu, PT. Indonesia Power juga selalu memberikan himbauan kepada pengelolan pariwisata dan juga wisatawan agar selalu menjaga kebersihan terutama di wilayah Telaga Menjer. Hal ini dilakukan karena kegiatan pariwisata merupakan kegiatan yang menimbulkan kerumunan dan sampah sehingga dikhawatirkan akan mengganggu turbin untuk kegiatan pembangkit listrik.

Hal serupa juga berlaku untuk pengembangan pariwisata seperti pembangunan fasilitas, konsumsi energi untuk bangunan dan transportasi, penggunaan air yang berlebihan serta timbulan sampah dan pembuangannya bertanggung jawab kepada degradasi lingkungan (Lee and Syah, 2018; Hasyir et al., 2020).

\section{d. Karang Taruna Karya Persada}

Karang Taruna Karya Persada awal terbentuk dari permasalahan sosial yaitu pemuda Desa Maron yang suka mabuk, memalak dan mencuri. Melihat warga sekitar. Karang Taruna Karya Persada 
memiliki visi Peduli, Berdaya, Mandiri. Misi

Karang Taruna Karya Persada yaitu; melatih warga Karang Taruna Karya Persada untuk peduli kepada masyarakat dan lingkungan alam; meningkatkan standar ekonomi warga Karang Taruna Karya Persada dengan program pemberdayaan. Sasaran kegiatan dari Karang Taruna Karya Persada meliputi; warga yang tergabung dalam Karng Taruna Karya Persada; PMKS dan masyarakat umum; lingkungan sekitar.

Karang Taruna Karya Persada dibentuk pada tahun 2010, namun sempat vakum selama tiga tahun dan pada moment Agustusan Karang Taruna mulai aktif kembali. Awal kegiatan lebih memfokuskan pada Penyandang Masalah Kesejahteraan Sosial (PMKS) yang meliputi anak-anak, fakir miskin, perempuan dan difabel. Program pembersihan eceng gondok ini menjadi rutinitas bagi Karang Taruna Karya Persada dan Warga Desa Maron. Warga Desa Maron dan Karang Taruna Karya Persada membersihkan eceng gondok yang kemudian dikumpulkan dan dibuat pupuk kompos. Pupuk kompos selanjutnya diserahkan kepada PT. Indonesia. Power sebagai pemilik lahan yang mengelilingi Telaga Menjer. Sebagai timbal baliknya PT Indonesia Power menawarkan kerjasama dengan Karang Taruna Karya Persada.

Sejak saat itu terbentuk kerjasama antara Karang Taruna Karya Persadadengan PT. Indonesia Power terkait pengelolaan wisata Telaga Menjer. Dengan adanya kegiatan rutin pembersihan telaga setiap hari jumat oleh warga Desa Maron dan Karang Taruna Karya Persada, maka tidak ada kekhawatiran dari PT Indonesia Power terkait kegiatan pariwisata karena ekosistem telaga lebih terjaga. Perjanjian kerjasama antara Karang Taruna dan PT Indonesia Power yang ditanda tangani pada pertengahan 2017 berisi terkait kewajiban warga Desa Maron dan Karang Taruna Karya Persada untuk menjaga lingkungan; menjaga kebersihan; serta membantu menjaga asetaset milik Indonesia Power yang ada di sekitar Telaga Menjer. Sebagai timbal baliknya Indonesia Power memberikan dukungan pada setiap kegiatan yang dilakukan oleh warga Desa Maron dan Karang Taruna Karya Persada.

\section{e. BUMDes Sumber Lancar Maron}

Badan Usaha Milik Desa Sumber Lancar Desa Maron Kecamatan Garung Kabupaten Wonosobo resmi dibentuk melalui musyawarah desa pada tanggal 15 Februari 2017 dan ditetapkan dengan Peraturan Desa No. 4 Tahun 2017. Selama dua tahun terakhir, BUMDes Sumber Lancar berjalan pada kegiatan pariwisata dan pamsimas (pengelolaan air bersih). Pada kegiatan pariwisata belum bisa di back-up secara optimal oleh Pemerintah Desa terkait penganggaran akan tetapi sudah bisa berjalan dengan baik. Sebagai sebuah unit kegiatan usaha BUMDes sudah mampu membiayai dalam hal operasional dan melakukan kegiatan pembangunan sarana dan prasarana yang sifatnya ringan.

Badan Usaha Milik Desa Sumber Lancar ini juga sebagai wadah bagi organisasi yang bergerak dibidang wisata Desa Maron. Sebelum adanya BUMDes Karang Taruna dan Pokdarwis Desa Maron sempat bentrok, lalu kemudian Kepala Desa membuat BUMDes agar mereka dapat bersama saling kerjasama dalam mengelola pariwisata yang ada di Desa Maron. Pada pengelolaan di Telaga Menjer BUMDes dan Karang Taruna Karya Persada bekerjasama dalam penjualan stiker sebagai salah satu ajang promosi BUMDes dan menambah kas BUMDes dan Karang Taruna. Hal ini diharapkan mampu menyerap semua potensi desa yang nantinya dapat dikelola oleh masyarakat dan berdampak bagi sosial ekonomi masyarakat Desa Maron.

Dengan adanya BUMDes ini menjamin masyarakat di Desa Maron untuk berpartisipasi dalam semua kegiatan yang ada disana. Pada kegiatan pariwisata sendiri misalnya semua lapisan masyarakat mempunyai peran dan fungsinya dalam pengembangan potensi pariwisata. Dengan demikian semua masyarakat dapat merasakan 
dampak ekonomi dan sosial secara langsung kegiatan pengembangan pariwisata di Desa Maron.

\section{f. Kelompok Sadar Wisata Desa Maron}

Kelompok Sadar Wisata Lembah Seroja merupakan salah satu komunitas pengembang pariwisata yang ada di Desa Maron Kecamatan Garung Kabupaten Wonosobo. Kelompok Sadar Wisata Lembah Seroja ini dibentuk dengan latar belakang untuk meningkatkan pembangunan daerah serta dengan berkembangnya dunia pariwisata di Indonesia dengan meningkatkan keterlibatan masyarakat sekitar obyek wisata dan didorong untuk menjadi subyek dari pengelolaan pariwisata di masa yang akan datang. Oleh karena itu sebagai bentuk pengokohan dari hal ini dilakukan diskusi multi pihak tentang pengembangan kepariwisataan di Telaga Menjer, sehingga disepakati dengan dibentuknya Kelompok Sadar Wisata (POKDARWIS) Lembah Seroja.

$$
\text { Pengembangan fasilitas dan }
$$

pengelolaan meliputi; pelengkapan dan penambahan fasilitas baik balai wisata, satwa, gardu pandang; camp ground maupun area out bound; pengelolaan yang menarik dan profesional sehingga menambah kenyamanan pengunjung. Pelestarian nilai budaya lokal yang meliputi; menggali potensi tentang nilai sejarah dan budaya lokal maupun kebiasaan yang dilakukan oleh warga sekitar; mMengemas potensi kebiasaan/tradisi yang menarik menjadi sebuah potensi pariwisata.

Pada pengelolaan pariwisata di Desa Maron sendiri, POKDARWIS Lembah Seroja hanya mengelola salah satu obyek wisata, yaitu Bukit Cinta. Telaga Menjer yang merupakan salah satu destinasi utama di Desa Maron tidak ikut dalam pengelolaannya. Hal ini dikarenakan dari awal Telaga Menjer sudah dikelola oleh Karang Taruna Karya Persada sehingga POKDARWIS sungkan untuk ikut campur. Rasa sungkan ini merupakan dampak dari konflik tarik ulur kepentingan antara Dinas Pariwisata dan Karang Taruna terkait pengelolaan Telaga Menjer. Sehingga Pokdarwis yang merupakan bianaan dari Dinas Pariwisata Kabupaten Wonosobo tidak ikut serta dalam pengelolaan Telaga Menjer

\section{Stakeholders Mapping CTCG di Desa Maron}

Stakeholders yang terlibat dalam pengembangan Community Tourism Collaborative Governance (CTCG) di Desa Maron memiliki pengaruh dan kepentingan yang berbeda-beda. Selain itu. perbedaan pengaruh dan kepentinganini yang menjadikan kurang meratanya Community Tourism Collaborative Governance di Desa Maron. Oleh karena itu, perlu dilakukannya pemetaan stakeholders berdasarkan pengaruh dan kepentingan dari masing- masing stakeholders yang terlibat.

Pemetaan stakeholders ini menggunakan skema yang juga digunakan oleh Handayani dalam penelitiannya di tahun 2017. Pada penelitiannya menetapkan "pengaruh" dan "kepentingan". Subyek, yaitu stakeholders dengan tingkat kepentingan tinggi tetapi memiliki pengaruh yang rendah. Pemain Kunci, yaitu stakeholderss dengan tingkat kepentingan dan pengaruh yang tinggi. Pengikut lain, stakeholders dengan tingkat kepentingan dan pengaruh yang rendah. Pendukung, stakeholders dengan tingkat kepentingan rendah dan memiliki pengaruh yang tinggi (Handayani dan Warsono, 2017; Triwahyuningtyas, Rahtomo dan Darmawan, 2018) Sehingga dapat dipetakan sebagai berikut: 
Sumber: Diolah Penulis 2021

\section{Gambar 1. Stakeholders Mapping CTCG Maron}

Pada pengelolaan dan pengembangan Community Torism Collaborative Governance di Desa Maron, stakeholder yang memiliki pengararuh besar ada 3 yaitu; Karang Taruna Karya Persada, Pemerintah Desa Maron dan juga BUMDes Sumber Lancar. Karang Taruna Karya Persada memiliki pengaruh yang sangat besar bagi pengembangan pariwisata di Desa Maron karena banyak kegiatan yang menunjang pariwisata diinisiasi oleh Karang Taruna. Kegiatan yang diinisiasi oleh Karang Taruna bahkan sampai sekarang masih berlanjut dan bervariasi, mulai dari pembersihan sampah dan eceng gondok di Telaga Menjer, kegiatan Jumat berbagi, penanaman pohon, tebar benih ikan, pengelolaan karamba, persewaan perahu, penanaman bibit kopi, pengelolaan Bukit Seroja, dan kerjasama dengan pihak ketiga.

Kegiatan yang dilakukan banyak melibatkan masyarakat sehingga hal ini yang menjadikan ada trust yang lebih besar kepada komunitas dari masyarakat. Selain itu adanya berbagai kerjasama yang dilakukan oleh Karang Taruna dengan pihak lokal juga menandakan pengaruh yang dimiliki oleh
Karang Taruna besar. Beberapa pihak swasta apabila akan menjadi investor banyak melalui Karang Taruna bukan dari Pemerintah Daerah. misalnya saja pada kerja sama yang dilakukan oleh Ketua Karang Taruna dengan PT Indonesia Power terkait penyewaan lahan yang berlangsung satu tahun, dan setiap tahun diperpanjang. Hal ini secara tidak langsung juga menjadikan Karang Taruna mempunyai kepentingan yang besar dalam Community Tourism Collaborative Governance (CTCG) dalam pengelolaan pariwisata yang ada di Desa Maron. Hal ini dikarenakan salah satu sumber anggaran dari berbagai kegiatan yang dilakukan oleh Karang Taruna dari pariwisata.

Pemerintah Desa sebagai otoritas lokal yang ada di Desa Maron memiliki pengaruh serta kepentingan yang tinggi juga. Pariwisata yang merupakan salah satu sektor yang mampu diharapkan sebagai solusi untuk kesejahteraan masyarakat menjadikan Pemerintah Desa mulai mengembangkan pariwisata. Pembentukan Badan Usaha Milik Desa ini menjadi salah satu bagian dari keseriusan Pemerintah Desa Maron untuk 
terus mengembangkan pariwisata. Selain itu juga Pemerintah Desa Maron memberikan dukungan dari segi perijinan dan legalitas setiap kegiatan pariwisata yang di lakukan oleh berbagai komunitas lokal yang ada di Desa Maron.

Berbeda dengan Pemerintah Desa Maron dan Karang Taruna Karya Persada Maron, Dinas Pariwisata dan Kebudayaan Kabupaten Wonosobo yang memiliki otoritas terkait kegiatan pariwisata yang ada di Wonosobo memiliki pengaruh yang rendah. Hal ini dikarenakan berbagai permasalahan yang terjadi di salah satu obyek wisata yang ada di Desa Maron. Konflik pengelolaan obyek wisata Telaga Menjer menjadikan masyarakat kehilangan kepercayaan kepada Dinas Pariwisata dan Kebudayaan Kabupaten Wonosobo. Hal ini disampaika oleh Kepala Desa Maron dan juga Ketua Karang Taruna bahwa sebelum Telaga Menjer bersih dan ramai wisatawan Dinas Pariwisata dan Kebudayaan Kabupaten Wonosobo tidak ada kepedulian sama sekali, namun setelah banyak wisatawan yang datang Dinas Pariwisata dan Kebudayaan Kabupaten Wonosobo ingin mengambil alih pengelolaan Telaga Menjer. Hal ini tentu saja dikarenakan besarnya pendapatan yang diperoleh dari obyek wisata Telaga Menjer.

Pemerintah Desa dan juga komunitas sempat menawarkan untuk dikelola bersamasama dengan menggunakan satu tiket terusan semua obyek wisata di Desa Maron dengan pembagian; Desa Maron 30\%, Dinas Pariwisata dan Kebudayaan Wonosobo 30\%, komuitas lokal $30 \%$ dan pengelola lapangan (ticketing) 10\%. Namun dari pihak Dinas Pariwisata dan Kebudayaan Kabupaten Wonosobo sendiri tidak menyetujui sehingga tidak ada kesepakatan. Selain itu juga pernah diadakan pertemuan antara Dinas Pariwisata dan Kebudayaan, Pemerintah Desa Maron, PT. Indonesia Power dan komunitas lokal terkait pengelolaan di Telaga Menjer. Pemerintah Desa dan komunitas mensyaratkan agar pemberdayaan masyarakat harus tetap ada, namun Dinas Pariwisata dan Kebudayaan Kabupaten Wonosobo tidak menyetujui. Sehingga dengan adanya hal diatas menjadikan distrust kepada Dinas Pariwisata dan Kebudayaan Kabupaten Wonosobo.

Adanya konflik kepentingan yang pernah terjadi di Telaga Menjer ini menjadikan salah satu komunitas lokal yaitu Kelompok Sadar Wisata Lembah Seroja tidak ikut serta mengelola obyek wisata. Kelompok Sadar Wisata Lembah Seroja yang merupkan komunitas yang dibentuk oleh Dinas Pariwisata dan Kebudayaan Kabupaten Wonosobo yang berfungsi untuk mengelola dan mengambangkan potensi wisata yang ada di wilayahnya tidak dapat berperan secara optimal. Hal tersebut juga dikemukaan oleh Pokdarwis bahwa kelompoknya tidak ikut mengelola sala satu obyek wisata dikarenakan dikhawatirkan akan menimbulkan konflik dengan komunitas lain.

PT. Indonesia Power sebagai salah satu pihak swasta memiliki pengaruh yang besar terhadap kegiatan parwisata yang ada di Desa Maron. Kegiatan pariwisata yang ada di Desa Maron secara tidak langsung sangat bergantung pada PT Indonesia Power, hal ini dikarenakan sebagian tanah dan wilayah air di sekitar obyek wisata Telaga Menjer adalah milik PT. Indonesia Power. Selain itu juga PT. Indonesia Power merupakan salah satu stakeholder yang memberikan dukungan finansial bagi beberapa komunitas lokal yang ada di Desa Maron. Sedangkan untuk kepentingan yang dimiiki oleh PT. Indonesia Power tidak begitu besar dalam pengembangan pariwisata. PT. Indonesia Power hanya menjalankan kewajiban CSR terhadap beberapa komunitas lokal serta keamanan desa dari kegiatan pembangkitan listrik.

Berdasarkan pemaparan diatas, berikut tabel ringkasan para stakeholderss serta peranannya yang terlibat dalam Community Tourism Collaborative Governance (CTCG) di Desa Maron:

Tabel 1 Analisis Peran Stakeholders 


\begin{tabular}{|c|c|c|}
\hline No & Stakeholders & Peran \\
\hline 1 & $\begin{array}{l}\text { Dinas Pariwisata } \\
\text { dan Kebudayaan } \\
\text { Kab. Wonosobo }\end{array}$ & $\begin{array}{l}\text { Perananan Dinas Pariwisata dan Kebudayan Kabupaten } \\
\text { Wonoosbo dalam Community Tourism Colaborative } \\
\text { Governance di Desa Maron: } \\
\text { - Regulator, membuat kebijakan terkait pengembangan } \\
\text { pariwisata secara umum di Kabupaten Wonosobo } \\
\text { - Pengelola sebagian kawasan obyek wisata Telaga } \\
\text { Menjer } \\
\text { - Membina Kelompok Sadar Wisata Lembah Seroja } \\
\text { Desa Maron }\end{array}$ \\
\hline 2 & $\begin{array}{l}\text { Pemerintah Desa } \\
\text { Maron }\end{array}$ & $\begin{array}{l}\text { - Pembina berbagai lembaga/ komunitas yang tergabung } \\
\text { dalam pengelolaan pariwisata di Desa Maron } \\
\text { Regulator, pembuat kebijakan terkait pengembangan } \\
\text { pariwisata di Desa Maron baik dari segi teknis maupun } \\
\text { anggaran. }\end{array}$ \\
\hline 3 & PT. Indonesia Power & $\begin{array}{l}\text { - Penyedia lahan disekitar Desa Maron yang digunakan } \\
\text { untuk masyarakat dan komunitas dalam pengembangan } \\
\text { pariwisata } \\
\text { - Menjaga keamanan daerah Ring } 1 \text { dari bencana akibat } \\
\text { kegiatan Pembangkitan Listrik yang dilakukan oleh } \\
\text { PLTA Garung } \\
\text { - Penyedian dana (CSR) untuk kegiatan sosial maupun } \\
\text { pengembangan pariwisata yang ada di Desa Maron }\end{array}$ \\
\hline 4 & $\begin{array}{ll}\text { BUMDes } & \text { Sumber } \\
\text { Lancar } & \\
\text { Desa Maron } & \\
\end{array}$ & $\begin{array}{l}\text { - Wadah untuk beberapa organisasi/ komunitas yang ada } \\
\text { di Desa Maron, termasuk komunitas yang bergerak di } \\
\text { bidang pariwisata }\end{array}$ \\
\hline 5 & $\begin{array}{l}\text { Karang Taruna Karya } \\
\text { Persada }\end{array}$ & $\begin{array}{l}\text { - Mengelola semua obyek wisata yang ada di Desa } \\
\text { Maron } \\
\text { Melakukan kerjasama dengan pihak luar baik } \\
\text { komunitas diluar Desa Maron maupun pihak swasta } \\
\text { guna mengoptimalkan pengembangan pariwisata yang } \\
\text { ada di Desa Maron. } \\
\text { - Memberdayakan masyarakat Desa Maron dalam } \\
\text { pengelolaan pariwisata yang ada di Desa Maron. } \\
\text { - Mengembangkan fasilitas pendukung pariwisata di } \\
\text { Desa Maron }\end{array}$ \\
\hline 6 & $\begin{array}{l}\text { Kelompok Sadar } \\
\text { Wisata }\end{array}$ & $\begin{array}{l}\text { - Mengelola beberapa obyek wisata yang ada di Desa } \\
\text { Maron } \\
\text { - Membuat rencana/ program kerja untuk } \\
\text { mengembangkan pariwisata yang ada di Desa Maron } \\
\text { (peningkatan fasilitas, kerjasama, promosi dll) }\end{array}$ \\
\hline
\end{tabular}

Sumber: Diolah Penulis 2021

Dilihat dari tabel diatas dapat dianalisis Stakeholders yang terlibat meliputi bahwa terdapat berbagai stakeholder yang Pemerintah Daerah seperti Dinas Pariwisata terlibat dalam Community Tourism dan Kebudayaan Kabupaten Wonosobo, Collaborative Governance (CTCG). Pemerintah Desa Maron serta Badan Usaha 
Milik Desa Sumber Lancar Maron. Sektor swasta tedapat PT. Indonesia Power serta dari masyarakat terdapat komunitas Karang Taruna Karya Persada Maron dan Kelompok Sadar Wisata Lembah Seroja. Kolaborasi dalam Community Tourism Collaborative Governance (CTCG) di Desa Maron dapat dikatakan luas, karena semua lapisan terlibat baik dari pemerintah, swasta serta masyarakat. Masyarakat yang menjadi sasaran utama dari tata kelola kolaboratif juga dilibatkan dalam setiap kegiatan serta pengambilan keputusan dalam pengelolaan pariwisaa yang ada di Desa Maron.

Namun hal lain yang perlu di perhatikan adalah kurang meratanya peran dari masing-masing stakeholders dalam Community Tourism Collaborative Governance (CTCG). Pemerintah daerah dalam hal ini Dinas Pariwisata dan Kebudayaan Kabupaten Wonosobo misalnya hanya berperan sebagai regulator saja dan kurang terlihat penuh dalam pengelolaan pariwisata yang ada di Desa Maron. Berbeda dengan penelitian yang dilakukan oleh Arif Sofianto di Kawasan Candi Borobudur yang menyebutkan terdapat Badan Pelaksana yang dapat melakukan hal seperti: (a) merencanakan peruntukan dan penggunaan tanah; (b) menggunakan tanah kawasan pariwisata untuk keperluan pengelolaan, pengembangan dan pembangunan; (c) menyewakan/ mengadakan kerjasama penggunaan, pemanfaatan dan pengelolaan tahan dengan pihak ketiga serta menerima pembayaran uang sewa (Sofianto, 2018). Namun yang terjadi hal tersebut dilakukan oleh pihak ketiga yaitu PT. Indonesia Power dan juga Karang Taruna melaui perjanjian kerjasama penggunaan lawan pariwisata.

Selain itu juga Kelompok Sadar Wisata Lembah (POKDARWIS) Seroja Maron yang tidak ikut serta dalam pengelolaan obyek wisata Telaga Menjer. Kolaborasi yang kurang merata nantinya dikhawatirkan akan menjadi konflik dan akan menghambat proses kolaborasi serta pengelolaan pariwisata yang ada di Desa Maron.
Sehingga perlu dilakukan upaya untuk pemerataan peran stakeholders dalam Community Torism Collaborative Governance (CTCG) di Desa Maron agar pengelolaan pariwisata dapat maksimal.

\section{SIMPULAN}

Berdasarkan analisis diatas, dapat disimpulkan hal-hal apa saja yang menjadikan Community Tourism Collaborative Governance (CTCG) di Desa Maron antara Dinas Pariwisata dan Kebudayaan Kabupaten Wonosobo, Pemerintah Desa Maron, PT. Indonesia Power, Badan Usaha Milik Desa Sumber Lancar Maron, Karang Taruna Karya Persada Maron, Kelompok Sadar Wisata Lembah Seroja Maron serta Masyarakat Desa Maron belum merata. Pada tata kelola kolaborasi pariwisata di Desa Maron sudah luas, hal ini dapat dilihat keterlibatan baik dari pemerintah daerah, swasta serta masyarakat yang tergabung dalam komunitas. Bahkan dalam pengelolaan dan pengembangan pariwisata yang ada di Desa Maron kelompok disabilitas yang tergabung dalam KSM Tali Kasih juga dilibatkan. Namun pembagian peran antar stakeholders masih belum merata khususnya dalam pengelolaan di Obyek Wisata Telaga Menjer. Pada pengelolaan di Obyek Wisata Telaga Menjer masih terdapat beberapa tarik ulur kepentingan antar stakeholders terutama dari pihak Dinas Pariwisata dan Kebudayaan Kabupaten Wonosobo dengan beberapa komunitas di sekitar Telaga Menjer. Selain itu beberapa komunitas tidak ikut serta dalam pengelolaan Telaga Menjer, kepemilikan beberapa obyek daya tarik wisata seperti gethek masih milik perorangan.

\section{SARAN}

Berdasakan hasil penelitian diatas, belum meratanya peran stakeholders dalam Community Tourism Collaborative Governance di Desa Maron disebabkan beberapa permasalahan. Untuk mengatasi 
Jurnal Litbang Provinsi Jawa Tengah, Vol. 19, No. 2, Desember 2021, hal. 123-136

permasalahan tersebut dibutuhkan beberapa saran agar tata kelola kolaborasi dapat berjalan optimal. Adapun beberapa rekomendasi yang dilakukan adalah Pemerintah Daerah harus memberikan dukungan penuh terkait regulasi maupun fasilitas pendampingan yang intens sebagai upaya pencapaian strategi serta mengembalikan kepercayaan masyarakat di Desa Maron. Selain itu perlunya koordinasi secara rutin antar stakeholder yang terlibat dalam pengelolaan pariwisata di Desa Maron sehingga tujuan dari pengembangam pariwisata dapat berjalan secara optimal. Terakhir, dengan adanya pemetaan stakeholder yang telah dilakukan oleh peneliti dapat dimanfaatkan untuk evaluasi serta memberikan kontribusi dalam menempatkan stakeholder yang sesuai dengan kemampuan dan kapasitas yang dimiliki sehingga pembagian peran bisa merata.

\section{DAFTAR PUSTAKA}

Ahsani, R. D. P. et al. (2018) 'Penerapan konsep community based tourism (CBT) di desa wisata candirejo borobudur mewujudkan kemandirian desa', Publisia: Jurnal Ilmu Administrasi Publik, 3(2), pp. 135146. doi: $10.26905 /$ pjiap.v3i2.2270.

Alamsyah, D. et al. (2019) 'Collaborative Governance dalam Mengembangkan Wisata Edukasi di Desa Kamiri Kecamatan Masamba Kabupaten Luwu Utara', FisiPublik: Jurnal Ilmu Sosial dan Politik, 04(02), pp. 112127.

Cresswell, J. W. (2012) Research Desaign: Pendekatan Kualitatif, Kuantitatif dan Mixed. Edited by A. Fawaid. Yogyakarta: Pustaka Pelajar.

Destiana, R. et al. (2020) 'Analisis Peran Stakeholders Dalam Pengembangan Destinasi Pariwisata Halal Di Pulau Penyengat Provinsi Kepulauan Riau Indonesia berdasarkan Global Muslim
Travel Index ( GMTI ) 2019 menjadi Pengembangan Destinasi Pariwisata mengenai sarana dan parasarana pe', Jurnal Ilmu Administrasi Negara (AsIAN), 08(02), pp. 132-153.

Al Fajri, D. N. A. (2019) 'Peran Stakeholder Dalam Upgrading Industri Pariwisata Melalui Desa Wisata (Studi Kasus: Pengembangan Desa Wisata Kembangarum Dan Desa Wisata Kasongan', Jurnal Studi Diplomasi, 11(1), pp. 60-70.

Handayani, F. and Warsono, H. (2017) 'Analisis Peran Stakeholders Dalam Pengembangan Objek Wisata Pantai Karang Jahe Di Kabupaten Rembang', pp. 1-13.

Hasyir, G. Al et al. (2020) 'Persepsi Dan Peran Pemangku Kepentingan Dalam Pengelolaan Kawasan Wisata Darajat Garut', Jurnal Komunikasi Universitas Garut: Hasil Pemikiran dan Penelitian, 6(1), pp. 412-425.

Hidayah, N. A. et al. (2019) 'Analisis Peran Stakeholder Dalam Pengembangan Wisata Talang Air Peninggalan Kolonial Belanda Di Kelurahan Pajaresuk Kabupaten Pringsewu Peran stakeholder dibutuhkan untuk mengoptimalkan pelaksanaan pembangunan termasuk pembangun', Jurnal Administrasi Publik, 7(1), pp. 55-71.

Irene, N. and Sitorus, B. (2020) 'Peran dan Kolaborasi Stakeholders Pariwisata dalam Mendukung Peningkatan Kunjungan Wisata di Kawasan Danau Toba', Jurnal Hospitality dan Pariwisata, 6(2), pp. 83-92.

Keyim, P. (2015) 'Collaboration and rural development in a tourism context', Tourism Development, (October), pp. 161-176.

Keyim, P. (2016) 'Tourism and rural development in western China: A case from Turpan', Community Development Journal, 51(4), pp. 534 551. doi: 10.1093/cdj/bsv046.

Keyim, P. (2018) 'Tourism Collaborative 
Governance and Rural Community Development in Finland: The Case of Vuonislahti', Journal of Travel Research, 57(4), pp. 483-494. doi: $10.1177 / 0047287517701858$.

Kusiawati, D. (2017) 'Pendidikan Luar Sekolah , Universitas Pendidikan Indonesia Pendidikan Luar Sekolah , Fakultas Ilmu Pendidikan, Universitas Negeri Malang', Pemberdayaan Masyarakat, 2(1), pp. 59-72.

Lee, J. W. and Syah, A. M. (2018) 'Economic and environmental impacts of mass tourism on regional tourism destinations in Indonesia', Journal of Asian Finance, Economics and Business, 5(3), pp. 31-41. doi: 10.13106/jafeb.2018.vol5.no3.31.

Sofianto, A. (2018) 'Strategi Pengembangan Kawasan Pariwisata Nasional Borobudur', Jurnal Litbang Provinsi Jawa Tengah, 16 Nomor 1, pp. 27-
44.

Thondhlana, G., Shackleton, S. and Blignaut, J. (2015) 'Local institutions, actors, and natural resource governance in Kgalagadi Transfrontier Park and surrounds, South Africa', Land Use Policy, 47, pp. 121-129. doi: 10.1016/j.landusepol.2015.03.013.

Triwahyuningtyas, E., Rahtomo, W. and Darmawan, H. (2018) 'Rencana Tata Kelola Destinasi Pariwisata Kawasan Pulau Camba-Cambang Dan Sekitarnya Di Kabupaten Pangkajene Dan Kepulauan', Jurnal Manajemen Resort dan Leisure, 15, No.1, pp. 3347.

Yashinta, P. N. (2020) 'Collaborative Governance Dalam Kebijakan Pembangunan Pariwisata Di Kabupaten Gianyar', Jurnal Ilmiah Dinamika Sosial, 4(1), pp. 1-23.

$136 \quad$ Ika Nur Afni Stakeholders Mapping dalam Pelaksanaan Community Tourism Collabortaive Governance (CTCG) di Desa 